\title{
Adjuvant Radiotherapy after Surgical Excision in Keloids
}

\author{
Jeong Won Lee (1) and Ki Ho Seol *(i) \\ Department of Radiation Oncology, Daegu Catholic University School of Medicine, Daegu 42472, Korea; \\ gardenlee@cu.ac.kr \\ * Correspondence: khseol@cu.ac.kr; Tel.: +82-53-650-4788
}

check for

updates

Citation: Lee, J.W.; Seol, K.H. Adjuvant Radiotherapy after Surgical Excision in Keloids. Medicina 2021, 57, 730. https://doi.org/10.3390/ medicina57070730

Academic Editor: Adam Reich

Received: 1 June 2021

Accepted: 18 July 2021

Published: 19 July 2021

Publisher's Note: MDPI stays neutral with regard to jurisdictional claims in published maps and institutional affiliations.

Copyright: (c) 2021 by the authors. Licensee MDPI, Basel, Switzerland. This article is an open access article distributed under the terms and conditions of the Creative Commons Attribution (CC BY) license (https:// creativecommons.org/licenses/by/ $4.0 /)$.

\begin{abstract}
Keloids are a benign fibroproliferative disease with a high tendency of recurrence. Keloids cause functional impairment, disfigurement, pruritus, and low quality of life. Many therapeutic options have been used for keloids. However, the high recurrence rates have led to the use of adjuvant therapy after surgical keloid excision. There are different radiotherapy regimens available, and the advantages and disadvantages of each are still unclear. The aim of this review is to explain the appropriate radiotherapy regimen for keloids as well as discuss the recent reports on keloid management with radiotherapy. Adjuvant radiotherapy after surgical excision for keloids yields excellent local control with tolerable side effects. Hypofractionated radiotherapy with a BED of more than 28 Gy $(\alpha / \beta$ value of 10$)$ after excision is recommended in the light of its biologic background.
\end{abstract}

Keywords: keloid; adjuvant radiotherapy; surgery

\section{Introduction}

Keloids are caused by interruption of the normal repair process and excessive scar formation following a skin injury such as piercing, trauma, and surgery. Keloids occur in $5 \%$ to $15 \%$ of wound healing cases [1]. They are classified as a benign disease with inflammatory conditions, but not as a tumor despite their fibroproliferative tendency [2]. These abnormal conditions can cause not only esthetic problems, owing to the presence of red, raised scars, but also uncomfortable symptoms such as itching, pain, and scar contracture. Unfortunately, spontaneous regression of keloids is rarely observed [3]. Several treatment modalities like interferons, intralesional steroid injections, cryotherapy, laser therapy, silicone gel sheets, pressure therapy, surgical excision, and radiotherapy have been used in the management of the keloids. However, a high recurrence rate (over 50\%) persists with these approaches [4,5]. Most authors have reported that the recurrence rate of keloids following surgical excision alone can be as high as 50\% to $80 \%$ [6,7]. Furthermore, it has previously been reported that surgical excision alone results in high recurrence rates of up to $100 \%$ and is thus ineffective as a treatment option for keloids [8,9], because the surgery itself may result in inflammation [2]. After the surgical excision of keloids, additional treatment modalities are needed, and radiotherapy has been used as a part of this combination therapy $[7,10,11]$. The international panel of experts on scar management stated that postoperative radiotherapy combined with surgical excision is the most effective treatment for keloids, even serious keloid lesions [12]. There are different radiotherapy regimens available, and the advantages and disadvantages of each are still unclear. We thus focus on adjuvant radiotherapy after excision for keloids in this review.

\section{The Mechanism of Adjuvant Radiotherapy}

Radiotherapy has been used in keloid treatment with or without surgery [12]. The mechanism by which radiotherapy exerts positive effects in the management of keloids is uncertain [13]. Keloids are characterized by abnormal overexpression of growth factors, such as platelet-derived growth factor, fibroblast growth factor, transforming growth factor$\alpha$, transforming growth factor- $\beta$, and interleukin, which are released during the wound 
healing process after injury. Transforming growth factor- $\beta$ is especially important for the development of keloids because of the association with fibroblast proliferation and formation of extracellular matrix components like collagen $[5,9,14]$. Its release from fibroblasts is hindered by radiation [15,16]; and thus, radiotherapy can prevent collagen synthesis and fibroblast proliferation, ultimately leading to inhibition of keloid formation [17-19].

According to Flickinger, radiotherapy reduces the extent of both normal and excessive wound healing by targeting rapidly growing fibroblasts, mesenchymal cells, and inflammatory cells $[20,21]$. In keloids, postoperative radiotherapy, which is administered to a more radiosensitive immature target after surgical excision, can lead to a better response than primary radiotherapy alone, which is administered to a mature target [22]. Several previous studies have reported good local control rates of $67 \%$ to $98 \%$ after postoperative radiotherapy for keloid treatment [23-25], and the recurrence rate of keloids following adjuvant radiotherapy after surgical excision $(<10 \%$ to $20 \%)$ was also shown to be significantly lower than that following treatment with primary radiotherapy alone [26,27].

\section{The Time Interval for Adjuvant Radiotherapy}

The time interval between surgical excision and radiotherapy is important but still controversial. Some studies have found that the time interval between surgical excision and radiotherapy did not affect treatment outcomes [13,28-32]. Hintz mentioned that a longer interval after excision is suitable for keloid treatment due to the fact that the radiosensitization effect can be timed to act during the proliferative stage of the cell cycle, but suggested that a short interval after surgery was effective only in earlobe keloids [33]. In contrast, other authors have suggested favorable disease control benefits of approximately $10 \%$ to $23 \%$ when radiotherapy is administered within $24 \mathrm{~h}$ after surgery [34-36]. The efficacy of a short time interval ( $24 \mathrm{~h}$ between surgery and adjuvant radiotherapy) is based on the above-mentioned prevention of fibroblast proliferation [17-19]. Therefore, adjuvant radiotherapy is widely used and initiated within $24 \mathrm{~h}$ after surgical excision [21].

\section{Radiation Technique}

In the past, the following radiotherapy modalities were used and shown to have similar success rates; many of these are still available today: external beam radiotherapy using either low-voltage photons from orthovoltage units or high-voltage electron or photon beams from linear accelerators; and brachytherapy, which can be applied with either low-dose rate iridium-192 seeds or by using a high-dose rate iridium-192 source with an after-loading machine [17].

Recently, several studies have supported the use of brachytherapy or electron irradiation $[27,37-40]$. However, these studies are limited by their retrospective designs, indirect comparison of radiation modalities, or old techniques that use kilovoltage $\mathrm{X}$-rays. The type of radiation to be used, thus, remains controversial. In a recent meta-analysis, the following different types of radiotherapy were analyzed in only the adjuvant setting following excision: brachytherapy, electron therapy, and X-rays [27]. The results demonstrated that brachytherapy had superior local control outcome than X-rays $(p=0.04)$, but there was no statistically significant difference between brachytherapy and electron therapy $(p=0.10)$. Since it was not a direct comparative study, it cannot be concluded that brachytherapy is superior based on a single meta-analysis. Brachytherapy has the disadvantage of not having equipment in all hospitals and being invasive. Electron beam therapy is already widely utilized and recommended in the treatment of keloids [41]. However, the inhomogeneity of the electron beam irradiation dose distribution in areas with a large slope does not allow the treatment of concave or convex volumes with a homogeneous dose [42]. Depending on the location of the keloid, proper selection of electrons and photons is required to obtain an appropriate dose distribution. Thus, external beam radiotherapy using electrons (Figure 1) or photons (Figure 2) seems to be a good modality because of their easy availability, high feasibility, and less invasiveness, when compared with brachytherapy. Recently, new at- 
tempts such as the use of helical tomotherapy for complicated keloids to overcome the limitations of the conventional electron or photon therapy have also been reported [43].
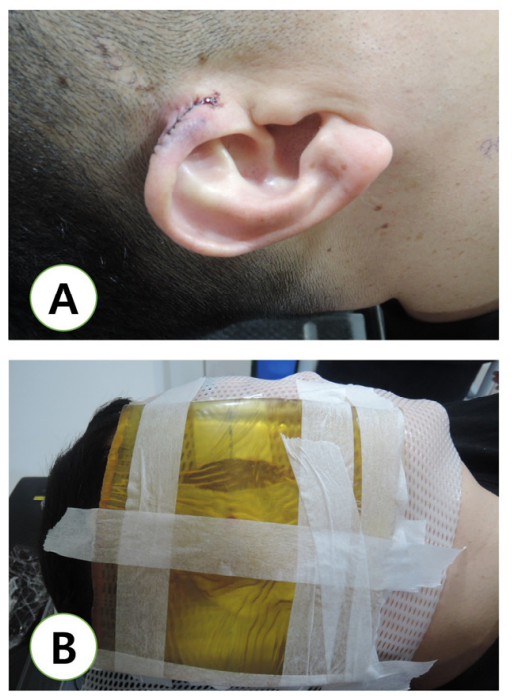

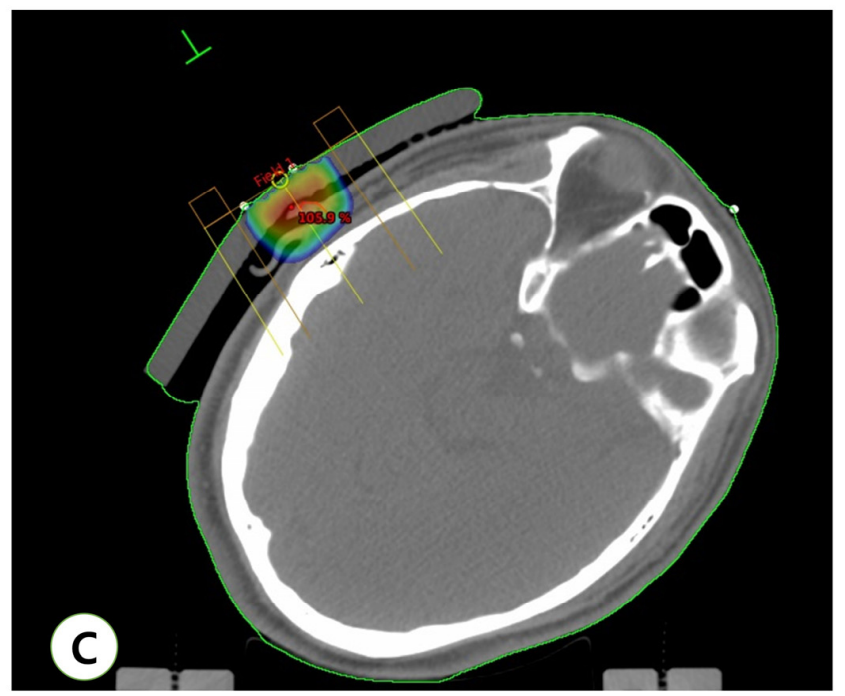

Figure 1. Example of computed tomography simulation for adjuvant radiotherapy using an electron beam. (A) Immediate post-operative view; (B) the patient was placed in a supine position and the head turned so that the ear to be treated was facing upward. A mask was used to immobilize the head. A part of the mask was excised to expose the area to be treated. A bolus was used to obtain a sufficient dose of the skin surface. The scar was marked with a wire. A margin of $1 \mathrm{~cm}$ around the scar was also marked with a wire to help with treatment planning; (C) computed tomography-based treatment plan for an ear keloid.
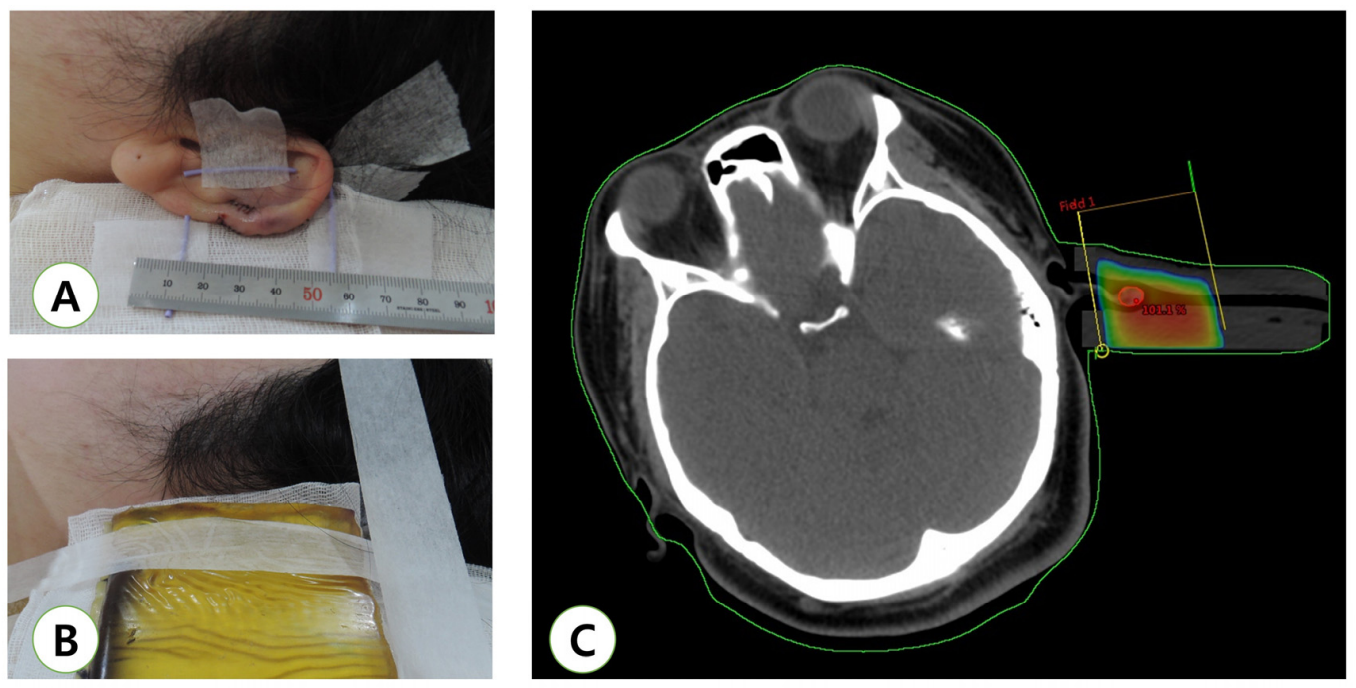

Figure 2. Example of adjuvant radiotherapy using a photon beam for an earlobe keloid. (A) Immediate post-operative view. (B) Simulation for radiotherapy. (C) Computed tomography-based treatment plan for an ear keloid.

The target volume usually includes a $10 \mathrm{~mm}$ radial margin around the scar and all the suture lines. The goal depth should be assessed using imaging devices prior to surgery (e.g., ultrasound), with an additional safety margin of at least 5-10 $\mathrm{mm}$ being provided [17]. Depending on the site of the scar and concern for irradiated dose to the adjacent tissue and organ, either a clinical or computed tomography simulation can be used. Depending on the expected dose distribution, bolus can be added to the irradiated area to provide an adequate surface dose to the scar. Lead shields or absorbers can be positioned near the field to block irradiated doses from reaching the adjacent critical structures. The actual selection of the planned radiotherapy technique is based on the location and size of the wound. 


\section{Radiation Dose and Fractionation}

No research-based standardized treatment schedule exists for the use of post-surgical radiation despite radiation therapy having been in keloid treatment for decades. The optimal radiation dose and fractionation for keloids is still not known [2]. Kal and Veen hypothesized that an $\alpha / \beta$ value of 10 for keloids at the early responding tissues [18]. Use of the linear-quadratic model to calculate a biologically effective dose (BED) for various therapeutic adjuvant radiotherapy regimens showed that when a BED exceeds $30 \mathrm{~Gy}_{10}$, the recurrence rate is less than $10 \%$. Therefore, they recommended a BED greater than $30 \mathrm{~Gy}_{10}$. On the other hand, Flickinger researched the $\alpha / \beta$ value of keloids and found it to be as low as two, thus demonstrating the efficacy of hypofractionated radiotherapy [20]. An in vitro study by Malaker et al. suggested a fraction size of $5 \mathrm{~Gy}$ for radiolysis of fibroblasts, but single irradiation with a large fraction size increases the possibility of treatment failure and skin necrosis [44,45]. Many authors have investigated the dosedependent correlation of recurrence rate and have advocated $20 \mathrm{~Gy}$ in five fractions as an appropriate dose fractionation schedule $[13,46]$. Renz et al. reported the results of a retrospective study comparing the outcomes of two regimens of postoperative radiotherapy in 250 keloid lesions ( 125 keloids were treated with $20 \mathrm{~Gy}$ in five fractions while the other 125 keloids were treated with 12 to 16 Gy in 3 to 4 fractions) [46]. They reported that the lesions treated with a dose of $20 \mathrm{~Gy}$ had a recurrence rate of $1.6 \%$ compared with a rate of $9.6 \%$ in those lesions treated with $<20$ Gy (odds ratio: $0.16, p=0.02$ ). The BED of $20 \mathrm{~Gy}$ in five fractions was converted into $28 \mathrm{~Gy}_{10}$ or $60 \mathrm{~Gy}_{2}$ in a study by Flickinger [20]. Therefore, hypofractionated radiotherapy with a BED of more than $28 \mathrm{~Gy}(\alpha / \beta$ value of 10) showed superior local control compared with treatment using lower dose regimens. Further investigation on fractionation regimen that effectively prevent recurrence without elevating the risk of secondary carcinogenesis is helpful.

\section{Clinical Outcomes of Adjuvant Radiotherapy}

Numerous studies have proved the contentable result of surgery followed by radiotherapy for the treatment of keloids. A literature review of over 70 studies displayed that radiotherapy after surgical excision significantly decreased recurrence rates $(22 \% \pm 4 \%)$ compared with radiotherapy alone (recurrence rate of $37 \% \pm 12 \%$ ) [27]. Figure 3 shows an example of successful earlobe keloid treatment with surgical excision and adjuvant radiotherapy.
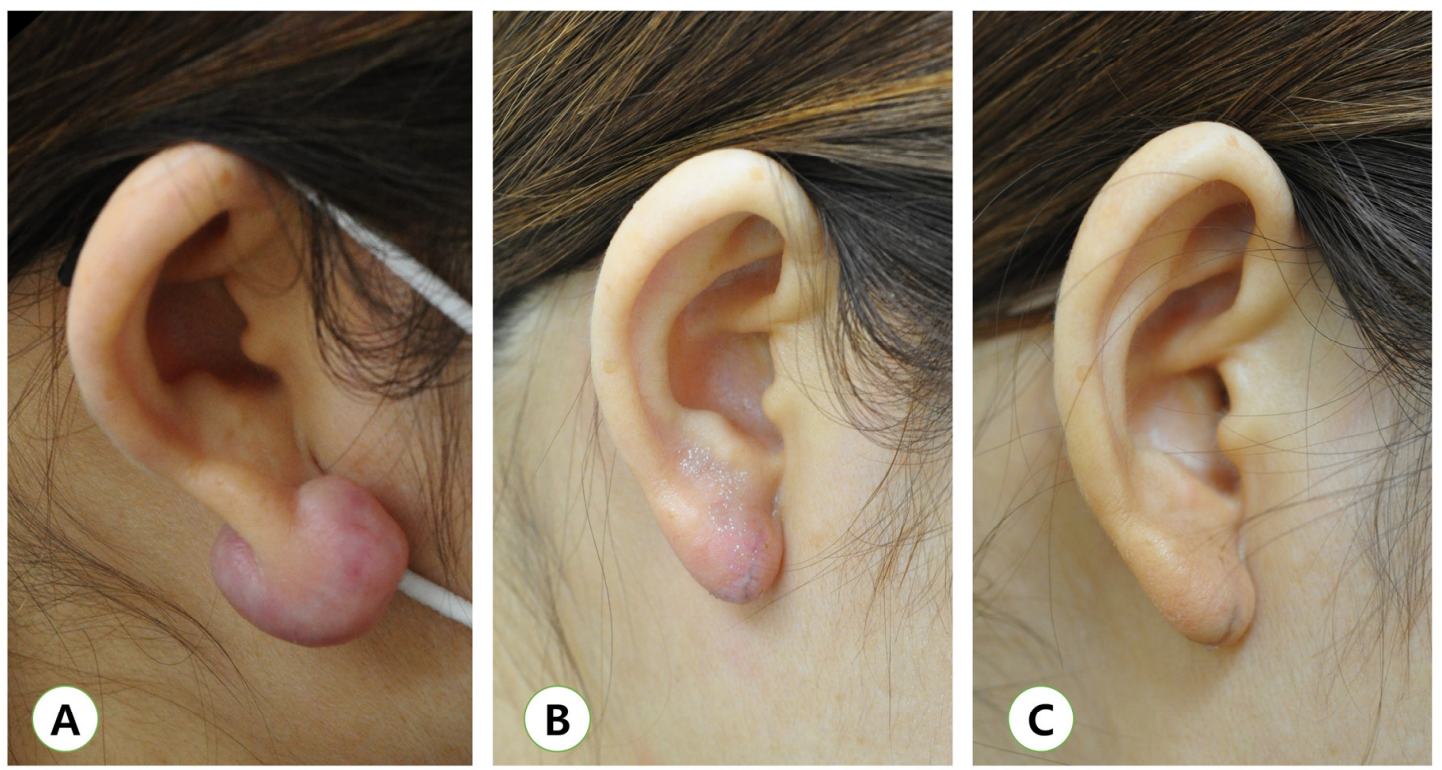

Figure 3. (A) Pre-operative view, (B) immediately post-radiotherapy (20 Gy in five fractions following excision of keloids). Radiotherapy was initiated within $24 \mathrm{~h}$ after the excision. No treatment-related complication was noted. (C) One-year follow-up image of following treatment with adjuvant radiotherapy. No recurrence of the elevation of the mass was noted. 
The same meta-analysis revealed the different recurrence rates by the site of keloid lesions. In respect of the site of keloid lesion, the lesions located on the chest and trunk had the highest recurrence rate of $34 \%$ compared with the lesions on the ear, head and neck, or extremities. Keloids localized on the ear were found to have the lowest rate of recurrence $(12 \%)$ [27]. The difference in the tensile strength of the skin in each of these areas may cause this variation in recurrence rates by the site of lesions.

\section{Complications after Radiotherapy}

In general, the application of relatively low total radiation doses does not stimulate skin and soft tissue reactions beyond the common toxicity criteria (CTC) level of Grade 1-2 [17]. Acute and late complications are generally minor, and the most common side effects are skin damage such as erythema, desquamation, and pigmentation. These were observed in $25 \%$ of cases reported in existing literature and were seen when higher total radiation dose was used $[47,48]$. An analysis of 194 patients with keloids reported that the incidence of moderate-to-severe skin reactions (hyperpigmentation, depigmentation, and telangiectasis) was 19\%, but none of the patients had critical complications of CTC grade 3 or higher [13]. Other studies have demonstrated very low incidence rates of less than $1 \%$ or no incidence rate for serious complications with wound infection or dehiscence [27,34,49]. To improve and accelerate the skin regeneration process, the patient should be instructed to apply hydrating products, such as aloe vera gel or glycerol, locally over the lesion for a few weeks after the post-surgical dressing has been removed.

There is concern about the risk of secondary malignancies due to radiation exposure. After radiotherapy of keloid, the main risk to be considered is the induction of malignant disease by the radiation exposure of critical organs in the field and from scatter. Ogawa et al. found five cases recorded as radiation-induced malignant tumors in keloid patients [24]. However, the relationship with radiotherapy was ambiguous in most of them. Thus, they concluded that the risk of radiation-induced secondary malignancy is very slight. Other authors have stated no association between secondary malignancy and the use of radiotherapy in keloids $[13,25,27,36,48]$. Although the safety of the radiotherapy in keloid has been established, attention should be paid to radiosensitive organs such as thyroid gland and mammary gland in treatment planning and radiation delivery.

\section{Conclusions}

The present review summarizes the usefulness of adjuvant radiotherapy following surgical excision in the treatment of keloids. This overview will benefit practitioners by providing them evidence-based strategies for the treatment of keloids, that is, use of adjuvant radiotherapy following surgical excision.

Adjuvant radiotherapy after surgical excision for keloids yields excellent local control and has tolerable side effects. Hypofractionated radiotherapy with a BED of more than $28 \mathrm{~Gy}(\alpha / \beta$ value of 10 ) within $24 \mathrm{~h}$ after excision is recommended in light of its biologic background.

Author Contributions: Conceptualization: K.H.S. Methodology: K.H.S. and J.W.L. Validation: K.H.S. and J.W.L. Resources: K.H.S. Data curation: K.H.S. and J.W.L. Visualization: K.H.S. Writing—original draft: J.W.L. Writing—review and editing: K.H.S. Visualization: K.H.S. Supervision: K.H.S. All authors have read and agreed to the published version of the manuscript.

Funding: This research received no external funding.

Institutional Review Board Statement: Not applicable.

Informed Consent Statement: Written informed consent has been obtained from the patients to publish this paper.

Data Availability Statement: Not applicable.

Conflicts of Interest: The authors declare no conflict of interest regarding publication of this review. 


\section{References}

1. Wittenberg, G.P.; Fabian, B.G.; Bogomilsky, J.L.; Schultz, L.R.; Rudner, E.J.; Chaffins, M.L.; Saed, G.M.; Burns, R.L.; Fivenson, D.P. Prospective, single-blind, randomized, controlled study to assess the efficacy of the 585-nm flashlamp-pumped pulsed-dye laser and silicone gel sheeting in hypertrophic scar treatment. Arch. Dermatol. 1999, 135, 1049-1055. [CrossRef] [PubMed]

2. Ogawa, R. Keloids and Hypertrophic Scars Can Now Be Treated Completely by Multimodal Therapy, Including Surgery, Followed by Radiation and Corticosteroid Tape/Plaster. In Scars; Chiriac, A., Ed.; IntechOpen: London, UK, 2019. [CrossRef]

3. Barsky, A.J.; Kahn, S.; Simon, B.E. Principles and Practices of Plastic Surgery, 2nd ed.; McGraw-Hill Pub. Co.: New York, NY, USA; Toronto, ON, Canada; London, UK, 1964; pp. 170-172.

4. Berman, B.; Bieley, H.C. Keloids. J. Am. Acad. Dermatol. 1995, 33, 117-123. [CrossRef]

5. Marneros, A.G.; Krieg, T. Keloids—clinical diagnosis, pathogenesis, and treatment options. JDDG 2004, 2, 905-913. [CrossRef]

6. Cosman, B.; Wolff, M. Bilateral earlobe keloids. Plast. Reconstr. Surg. 1974, 53, 540-543. [CrossRef]

7. Escarmant, P.; Zimmermann, S.; Amar, A.; Ratoanina, J.L.; Moris, A.; Azaloux, H.; Francois, H.; Gosserez, O.; Michel, M.; G'Baguidi, R. The treatment of 783 keloid scars by iridium 192 interstitial irradiation after surgical excision. Int. J. Radiat. Oncol. Biol. Phys. 1993, 26, 245-251. [CrossRef]

8. Arno, A.I.; Gauglitz, G.G.; Barret, J.P.; Jeschke, M.G. Up-to-date approach to manage keloids and hypertrophic scars: A useful guide. Burn. J. Int. Soc. Burn Inj. 2014, 40, 1255-1266. [CrossRef]

9. Niessen, F.B.; Spauwen, P.H.; Schalkwijk, J.; Kon, M. On the nature of hypertrophic scars and keloids: A review. Plast. Reconstr. Surg. 1999, 104, 1435-1458. [CrossRef]

10. van de Kar, A.L.; Kreulen, M.; van Zuijlen, P.P.; Oldenburger, F. The results of surgical excision and adjuvant irradiation for therapy-resistant keloids: A prospective clinical outcome study. Plast. Reconstr. Surg. 2007, 119, 2248-2254. [CrossRef]

11. Veen, R.E.; Kal, H.B. Postoperative high-dose-rate brachytherapy in the prevention of keloids. Int. J. Radiat. Oncol. Biol. Phys. 2007, 69, 1205-1208. [CrossRef]

12. Mustoe, T.A.; Cooter, R.D.; Gold, M.H.; Hobbs, F.D.; Ramelet, A.A.; Shakespeare, P.G.; Stella, M.; Téot, L.; Wood, F.M.; Ziegler, U.E. International clinical recommendations on scar management. Plast. Reconstr. Surg. 2002, 110, 560-571. [CrossRef]

13. Sakamoto, T.; Oya, N.; Shibuya, K.; Nagata, Y.; Hiraoka, M. Dose-response relationship and dose optimization in radiotherapy of postoperative keloids. Radiother. Oncol. J. Eur. Soc. Ther. Radiol. Oncol. 2009, 91, 271-276. [CrossRef] [PubMed]

14. Fujiwara, M.; Muragaki, Y.; Ooshima, A. Keloid-derived fibroblasts show increased secretion of factors involved in collagen turnover and depend on matrix metalloproteinase for migration. Br. J. Dermatol. 2005, 153, 295-300. [CrossRef]

15. Lee, S.Y.; Park, J. Postoperative electron beam radiotherapy for keloids: Treatment outcome and factors associated with occurrence and recurrence. Ann. Dermatol. 2015, 27, 53-58. [CrossRef]

16. Stadelmann, W.K.; Digenis, A.G.; Tobin, G.R. Physiology and healing dynamics of chronic cutaneous wounds. Am. J. Surg. 1998, 176, 26S-38S. [CrossRef]

17. GuIx, B.; Andres, A.; Salort, P.; Tello, J.I.; Henriquez, I.; Lejarcegui, J.A.; Seegenschmiedt, M.H. Chapter 11 Keloids and Hypertrophic Scars. In Radiotherapy for Non-Malignant Disorder; Seegenschmiedt, M.H., Makoski, H.B., Trott, K.R., Brady, L.W., Eds.; Springer: Berlin, Germany, 2008; Volume 2008, pp. 208-224.

18. Kal, H.B.; Veen, R.E. Biologically effective doses of postoperative radiotherapy in the prevention of keloids. Dose-Effect Relatsh. Strahlenther. Onkol. Organ Dtsch. Rontgenges. 2005, 181, 717-723. [CrossRef]

19. Luo, S.; Benathan, M.; Raffoul, W.; Panizzon, R.G.; Egloff, D.V. Abnormal balance between proliferation and apoptotic cell death in fibroblasts derived from keloid lesions. Plast. Reconstr. Surg. 2001, 107, 87-96. [CrossRef] [PubMed]

20. Flickinger, J.C. A radiobiological analysis of multicenter data for postoperative keloid radiotherapy. Int. J. Radiat. Oncol. Biol. Phys. 2011, 79, 1164-1170. [CrossRef] [PubMed]

21. Winkfield, K.M.; Iris, J.G.B.; Tony, C.G.; Eng, Y.; Charles, R.T. Nonmalignant Disease. In Perez and Brady's Principles and Practice of Radiation Oncology, 6th ed.; Halperin, E.C., Perez, C.A., Brady, L.W., Eds.; Lippincott Williams \& Wilkins: Philadelphia, PA, USA, 2013; pp. 1749, 2013.

22. Bischof, M.; Krempien, R.; Debus, J.; Treiber, M. Postoperative electron beam radiotherapy for keloids: Objective findings and patient satisfaction in self-assessment. Int. J. Dermatol. 2007, 46, 971-975. [CrossRef] [PubMed]

23. Al-Attar, A.; Mess, S.; Thomassen, J.M.; Kauffman, C.L.; Davison, S.P. Keloid pathogenesis and treatment. Plast. Reconstr. Surg. 2006, 117, 286-300. [CrossRef]

24. Ogawa, R.; Yoshitatsu, S.; Yoshida, K.; Miyashita, T. Is radiation therapy for keloids acceptable? The risk of radiation-induced carcinogenesis. Plast. Reconstr. Surg. 2009, 124, 1196-1201. [CrossRef]

25. Xu, J.; Yang, E.; Yu, N.Z.; Long, X. Radiation Therapy in Keloids Treatment: History, Strategy, Effectiveness, and Complication. Chin. Med. J. 2017, 130, 1715-1721. [CrossRef]

26. Chaudhry, M.R.; Akhtar, S.; Duvalsaint, F.; Garner, L.; Lucente, F.E. Ear lobe keloids, surgical excision followed by radiation therapy: A 10-year experience. Ear Nose Throat J. 1994, 73, 779-781. [CrossRef]

27. Mankowski, P.; Kanevsky, J.; Tomlinson, J.; Dyachenko, A.; Luc, M. Optimizing Radiotherapy for Keloids: A Meta-Analysis Systematic Review Comparing Recurrence Rates Between Different Radiation Modalities. Ann. Plast. Surg. 2017, $78,403-411$. [CrossRef]

28. Borok, T.L.; Bray, M.; Sinclair, I.; Plafker, J.; LaBirth, L.; Rollins, C. Role of ionizing irradiation for 393 keloids. Int. J. Radiat. Oncol. Biol. Phys. 1988, 15, 865-870. [CrossRef] 
29. Enhamre, A.; Hammar, H. Treatment of keloids with excision and postoperative X-ray irradiation. Dermatologica 1983, 167, 90-93. [CrossRef]

30. Hsueh, W.T.; Hung, K.S.; Chen, Y.C.; Huang, Y.T.; Hsu, C.K.; Ogawa, R.; Hsueh, Y.Y. Adjuvant Radiotherapy After Keloid Excision: Preliminary Experience in Taiwan. Ann. Plast. Surg. 2019, 82, S39-S44. [CrossRef]

31. Kovalic, J.J.; Perez, C.A. Radiation therapy following keloidectomy: A 20-year experience. Int. J. Radiat. Oncol. Biol. Phys. 1989, 17, 77-80. [CrossRef]

32. Recalcati, S.; Caccialanza, M.; Piccinno, R. Postoperative radiotherapy of auricular keloids: A 26-year experience. J. Dermatol. Treat. 2011, 22, 38-42. [CrossRef]

33. Hintz, B.L. Radiotherapy for keloid treatment. J. Natl. Med Assoc. 1973, 65, 71-75.

34. Jiang, P.; Baumann, R.; Dunst, J.; Geenen, M.; Siebert, F.A.; Niehoff, P.; Bertolini, J.; Druecke, D. Perioperative Interstitial High-Dose-Rate Brachytherapy for the Treatment of Recurrent Keloids: Feasibility and Early Results. Int. J. Radiat. Oncol. Biol. Phys. 2016, 94, 532-536. [CrossRef]

35. Shen, J.; Lian, X.; Sun, Y.; Wang, X.; Hu, K.; Hou, X.; Sun, S.; Yan, J.; Yu, L.; Sun, X.; et al. Hypofractionated electron-beam radiation therapy for keloids: Retrospective study of 568 cases with 834 lesions. J. Radiat. Res. 2015, 56, 811-817. [CrossRef]

36. van Leeuwen, M.C.; Stokmans, S.C.; Bulstra, A.E.; Meijer, O.W.; Heymans, M.W.; Ket, J.C.; Ritt, M.J.; van Leeuwen, P.A.; Niessen, F.B. Surgical Excision with Adjuvant Irradiation for Treatment of Keloid Scars: A Systematic Review. Plastic and reconstructive surgery. Glob. Open 2015, 3, e440. [CrossRef]

37. Arneja, J.S.; Singh, G.B.; Dolynchuk, K.N.; Murray, K.A.; Rozzelle, A.A.; Jones, K.D. Treatment of recurrent earlobe keloids with surgery and high-dose-rate brachytherapy. Plast. Reconstr. Surg. 2008, 121, 95-99. [CrossRef]

38. Duan, Q.; Liu, J.; Luo, Z.; Hu, C. Postoperative brachytherapy and electron beam irradiation for keloids: A single institution retrospective analysis. Mol. Clin. Oncol. 2015, 3, 550-554. [CrossRef]

39. Maarouf, M.; Schleicher, U.; Schmachtenberg, A.; Ammon, J. Radiotherapy in the management of keloids. Clinical experience with electron beam irradiation and comparison with X-ray therapy. Strahlenther. Onkol. Organ Dtsch. Rontgenges. 2002, 178, 330-335. [CrossRef]

40. Yossi, S.; Krhili, S.; Mesgouez-Nebout, N.; Vinchon-Petit, S.; Jadaud, E.; Tuchais, C.; Cellier, P.; Autret, D.; Rio, E.; Fernandez, L.; et al. Adjuvant treatment of keloid scars: Electrons or brachytherapy? Cancer Radiother. J. Soc. Fr. Radiother. Oncol. 2013, 17, 21-25. [CrossRef]

41. Ogawa, R.; Akita, S.; Akaishi, S.; Aramaki-Hattori, N.; Dohi, T.; Hayashi, T.; Kishi, K.; Kono, T.; Matsumura, H.; Muneuchi, G.; et al. Diagnosis and Treatment of Keloids and Hypertrophic Scars-Japan Scar Workshop Consensus Document 2018. Burns Trauma 2019, 7, 39. [CrossRef]

42. Weaver, R.D.; Gerbi, B.J.; Dusenbery, K.E. Evaluation of dose variation during total skin electron irradiation using thermoluminescent dosimeters. Int. J. Radiat. Oncol. Biol. Phys. 1995, 33, 475-478. [CrossRef]

43. Lin, Y.F.; Shueng, P.W.; Roan, T.L.; Chang, D.H.; Yu, Y.C.; Chang, C.W.; Kuo, A.T.; Chen, Y.S.; Hsiao, H.W.; Tien, H.J.; et al. Tomotherapy as an Alternative Irradiative Treatment for Complicated Keloids. J. Clin. Med. 2020, 9, 3732. [CrossRef]

44. Malaker, K.; Vijayraghavan, K.; Hodson, I.; Al Yafi, T. Retrospective analysis of treatment of unresectable keloids with primary radiation over 25 years. Clin. Oncol. 2004, 16, 290-298. [CrossRef]

45. Van Den Brenk, H.A.; Minty, C.C. Radiation in the management of keloids and hypertrophic scars. Br. J. Surg. 1960, 47, 595-605. [CrossRef]

46. Renz, P.; Hasan, S.; Gresswell, S.; Hajjar, R.T.; Trombetta, M.; Fontanesi, J. Dose Effect in Adjuvant Radiation Therapy for the Treatment of Resected Keloids. Int. J. Radiat. Oncol. Biol. Phys. 2018, 102, 149-154. [CrossRef]

47. Jiang, P.; Geenen, M.; Siebert, F.A.; Bertolini, J.; Poppe, B.; Luetzen, U.; Dunst, J.; Druecke, D. Efficacy and the toxicity of the interstitial high-dose-rate brachytherapy in the management of recurrent keloids: 5-year outcomes. Brachytherapy 2018, 17, 597-600. [CrossRef] [PubMed]

48. Wagner, W.; Alfrink, M.; Micke, O.; Schäfer, U.; Schüller, P.; Willich, N. Results of prophylactic irradiation in patients with resected keloids-a retrospective analysis. Acta Oncol. 2000, 39, 217-220. [CrossRef]

49. Ragoowansi, R.; Cornes, P.G.; Glees, J.P.; Powell, B.W.; Moss, A.L. Ear-lobe keloids: Treatment by a protocol of surgical excision and immediate postoperative adjuvant radiotherapy. Br. J. Plast. Surg. 2001, 54, 504-508. [CrossRef] 